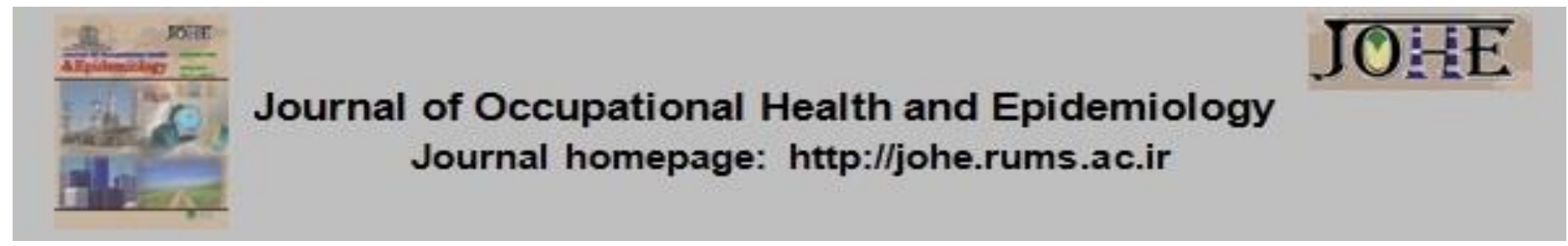

\title{
Is There any Possible Association Between Trimethylamine N-Oxide (TMAO) and Cancer? A Review Study
}

\author{
Adeleh khodabakhshi ${ }^{1 *}$, Mohammadreza Rooholamini ${ }^{2}$ \\ 1. Assistant Prof, Dept. of Nutrition, Faculty of Public Health, Kerman University of Medical Sciences, Kerman, Iran. \\ 2. Undergraduate Student, Dept. of Nutrition, Faculty of Public Health, Kerman University of Medical Sciences, Kerman, Iran.
}

\section{Article Info}

* Corresponding author:

Adeleh khodabakhshi,

E-mail:

Khodabakhshiadeleh@ yahoo.com

\section{Article history}

Received: Mar 2021

Accepted: May 2021

10.29252/johe.10.1.17

Print ISSN: 2251-8096 Online ISSN: 2252-0902

Peer review under
responsibility of Journal of
Occupational Health and
Epidemiology

Citation: Khodabakhshi A, Rooholamini M. Is There any Possible Association between

Trimethylamine N-Oxide (TMAO) and Cancer? A Review Study. JOHE 2021; 10(1):17-23.

\begin{abstract}
Background: During the transit of digested animal source foods, gut microbiota synthesize metabolites that can affect the body cells. One of these metabolites, i.e. Trimethylamine (TMA) that is an intermediary metabolite, ultimately leads to the production of Trimethylamine $\mathrm{N}$-oxide (TMAO). Several studies have been conducted to show the association between TMAO and different diseases. This article aimed to search literature in order to review published findings about the possible association between TMAO and cancer.
\end{abstract}

Materials and Methods: In this literature review, a comprehensive electronic search of different databases was done using "Trimethylamine $\mathrm{N}$-oxide" and "cancer" as the main keywords.

Result: Research suggests that TMAO can be related to the increased risk of cancer. The results showed a higher level of serum TMAO in cancer patients, most importantly colorectal cancer (CRC), than in healthy controls. Nevertheless, inflammation, oxidative stress, and DNA damage could be the reasons for the link between TMAO and cancer. Limiting dietary intake of animal products can reduce levels of TMAO.

Conclusion: It is concluded that a higher rate of TMAO production could potentially be associated with the development of different types of cancers, particularly CRC.

Keywords: Trimethylamine N-oxide, Cancer, Colorectal Cancer, Trimethylamine

\section{Introduction}

Cancer is a leading cause of death worldwide. There was an estimated rate of 19.3 million new cancer cases, accounting for nearly 10 million deaths in 2020. The overall incidence rate was higher in transitioned countries than in transitioning ones in both sexes [1].

Several factors can be responsible for the incidence of cancer [2-4]. One of the factors that has recently been shown to have a relationship with cancer, along with other diseases, is an organic compound called trimethylamine $\mathrm{N}$-oxide (TMAO) $[5,6]$. TMAO is produced by a precursor, i.e. trimethylamine (TMA), being a metabolite of various precursors, mainly choline and carnitine from ingested foods. The increase in TMAO levels can be attributed to two sources. The first source is TMA that is derived from precursor molecules by the action of gut bacteria and subsequent oxidation in the liver. The second one is dietary intake of TMAO-rich foods, such as red meat, eggs, milk, and certain fish products, including salmons [7, 8]. 
High levels of serum TMAO could be associated with the risk of Cardiovascular Disease (CVD) [911]. Research shows that by increasing cholesterol accumulation in macrophages and in foam cells of artery walls, TMAO contributes to atherosclerosis, thereby leading to cardiovascular disease [12]. According to animal studies, elevated levels of TMAO are directly associated with progressive organ fibrosis and dysfunction [13, 14]. The TMAO pathway and its metabolites are possibly involved in the development of two major health problems, including insulin resistance and cancer [15]. There is an association between high TMAO levels with low bacterial diversity and a change in the composition and distribution of bacterial phylotypes. Thus, a change in gut microbiota contributes to oncogenesis and tumor progression, both locally and systemically. Although inflammatory and metabolic cues support this phenomenon, additional mechanisms could attribute to the ability of dysbiosis to promote carcinogenesis [16]. We firstly describe TMAO and its formation pathways in brief. Next, we investigate the possible association that may exist between TMAO and cancer. Finally, we review recent studies on the potential correlation between TMAO and cancer.

\section{Materials and Methods}

A comprehensive review of electronic databases, including ISI web of knowledge, Scopus, and PubMed was made using the main keywords of "cancer" and "Trimethylamine $\mathrm{N}$-oxide". Besides, a manual search was done in the references of the articles gathered to improve the precision of the review. There were no restrictions on the date of publication. Randomized trials, case control studies, and prospective cohort studies were included for the purpose of this study. However, we excluded reviews and studies on animals, available articles with incomplete texts, and articles irrelevant to our topic.

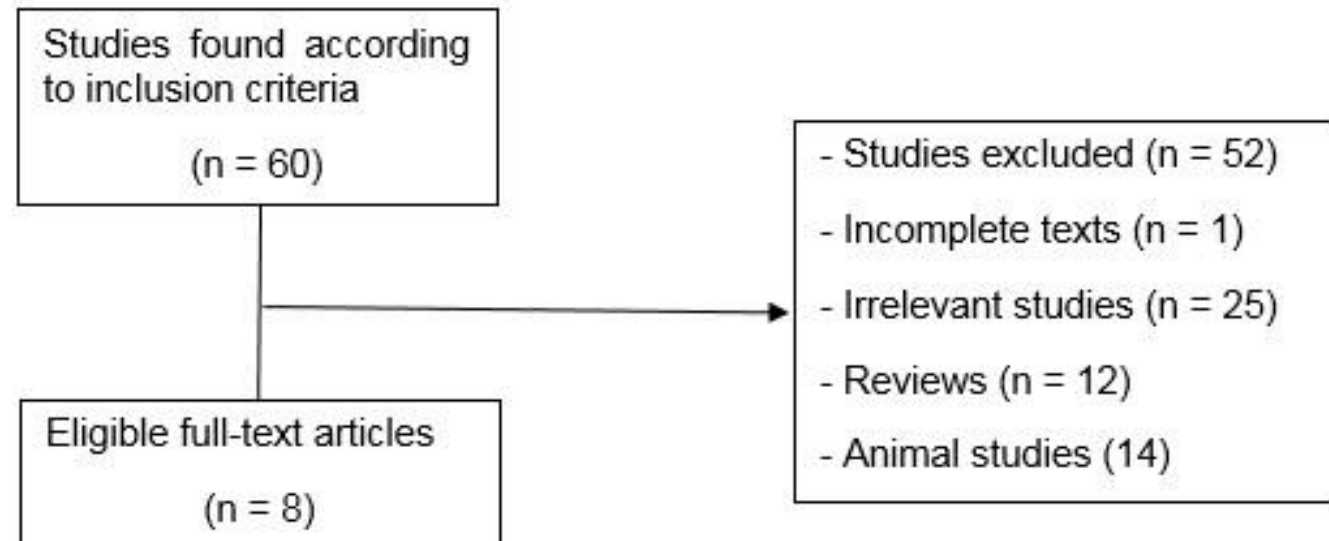

Fig. 1. Study selection

\section{Results}

TMAO and its formation pathway: Trimethylamine $\mathrm{N}$-oxide (TMAO) is a compound whose consideration in blood is dependent on the amount of phosphatidylcholine and L-carnitine produced after digestion of animal source foods [6, 17]. The production mechanism of TMAO in humans initiates with the digestion of food sources of two main TMAO precursors called L-carnitine and choline. These precursors are mostly found in animal source foods, such as red meat, milk, eggs, and several types of fish, particularly in salmons [7, 18]. Certain types of gut microbiome convert these molecules to an intermediate precursor for TMAO called trimethylamine (TMA) which is then absorbed by intestinal epithelium. Next it is transported to the liver by the bloodstream so as to be ultimately converted to TMAO by the enzymes of the Flavin Mono Oxygenase (FMO) family, in particular FMO-1 and FMO-3 isoforms [19]. In addition, different compounds found in foods may have a potential impact on the hepatic production of TMAO [20].

The possible association between TMAO and cancer: TMAO has the potential for causing malignant changes to body cells. TMAO has been identified as a metabolite with deleterious effects on exposed cells. Such effects can be exerted by the formation of $\mathrm{N}$-Nitroso compounds, thereby leading to DNA damage [21, 22]. In addition, high consumption of animal source foods can contribute to the formation of TMAO and its precursors. This may increase the risk of cancer in the gastrointestinal (GI) tract, and in particular, colorectal cancer (CRC) [23]. In a retrospective study in 2017, results of 108 patients with 
colorectal cancer and 30 healthy controls showed that pretreatment serum levels of TMAO were higher in CRC patients than in the healthy control group. This could be a prognostic marker for CRC [24]. In a case-control study conducted on women in the United States, the plasma TMAO levels were positively associated with CRC risks. In another study, participants in the highest quartile of plasma TMAO concentrations were shown to be at a higher risk of rectal cancer (by 3.4 times) than those in the lowest quartile of plasma TMAO concentrations. This study verified the presence of a positive association between plasma TMAO levels and the risk of colorectal cancer [25].

It could be concluded that TMAO is responsible for CRC. However, several studies reject such linkage, in which TMAO has been shown to have a protective effect on carcinogenesis by correcting folding defects of mutant proteins [26, 27].

TMAO may be responsible for offsetting protective effects of alpha-casein, i.e. a milk protein acting as a tumor suppressor via activation of STAT1 signaling. It can also be a preventive factor against cancer tumor growth and metastasis [28, 29].

Evidence suggests that inflammation could be a causing factor for the link between TMAO and cancer. TMAO has been found to activate the signaling of nuclear factor-KB (NF-KB) [30]. According to a study in Germany, there is a positive association between plasma TMAO concentrations and TNF- $\alpha$ levels. Furthermore, serum levels of TMAO were shown to be associated with TNF- $\alpha$ and IL- 6 in diabetic patients with chronic kidney disease. Both TNF- $\alpha$ and IL-6 can induce chronic inflammation, which can be carcinogenic [31] and may explain carcinogenicity of TMAO.

There are associations between high TMAO levels, low bacterial diversity, and a change in the composition and distribution of bacterial phylotypes. Past research shows that a change in the composition of microbiomes could be correlated with the increased risk of CRC, breast cancer [32], and gastric cancers [33].

Oxidative stress is another pathway between TMAO and cancer. Increased levels of TMAO circulation result into superoxide production, i.e. a reactive oxygen species (ROS) linked to oxidative stress [34]. Oxidative stress was revealed to contribute to carcinogenesis [35].

Table 2. Details of included human studies

\begin{tabular}{|c|c|c|c|c|c|}
\hline Author & $\begin{array}{l}\text { Year of } \\
\text { study }\end{array}$ & Sample size & Type of study & Research objectives & Results \\
\hline $\begin{array}{l}\text { Guertin } \\
\text { et al (23) }\end{array}$ & 2017 & $\begin{array}{l}644 \mathrm{CRC} \text { cases } \\
\text { and } 644 \text { controls }\end{array}$ & $\begin{array}{l}\text { Case-control } \\
\text { study }\end{array}$ & $\begin{array}{c}\text { To investigate the relationship } \\
\text { between serum concentrations of } \\
\text { TMAO and its precursors (choline, } \\
\text { carnitine, and betaine) and } \\
\text { incidence of CRC in male } \\
\text { smokers }\end{array}$ & $\begin{array}{c}\text { Higher serum choline } \\
\text { concentrations (but not TMAO, } \\
\text { carnitine, or betaine) were } \\
\text { associated with the risk of CRC }\end{array}$ \\
\hline $\begin{array}{l}\text { Liu et al } \\
\qquad(24)\end{array}$ & 2017 & $\begin{array}{l}108 \mathrm{CRC} \text { cases } \\
\text { and } 30 \text { healthy } \\
\text { controls }\end{array}$ & $\begin{array}{l}\text { Case-control } \\
\text { study }\end{array}$ & $\begin{array}{l}\text { To determine whether TMAO is a } \\
\text { predictor of patients with CRC }\end{array}$ & $\begin{array}{l}\text { Median serum TMAO levels } \\
\text { were significantly higher in CRC } \\
\text { patients than in healthy controls. }\end{array}$ \\
\hline $\begin{array}{l}\text { Bae et al } \\
\quad(25)\end{array}$ & 2014 & $\begin{array}{l}835 \mathrm{CRC} \text { cases } \\
\text { and } 835 \text { controls }\end{array}$ & $\begin{array}{l}\text { Case-control } \\
\text { study }\end{array}$ & $\begin{array}{l}\text { To examine the association } \\
\text { between plasma choline } \\
\text { metabolites and the risk of CRC }\end{array}$ & $\begin{array}{l}\text { Positive associations between } \\
\text { plasma TMAO and the CRC risk }\end{array}$ \\
\hline $\begin{array}{l}\text { Griffin } \\
\text { et al (41) }\end{array}$ & 2019 & $\begin{array}{l}115 \text { healthy } \\
\text { people at the risk } \\
\text { of CRC }\end{array}$ & $\begin{array}{l}\text { Randomized } \\
\text { controlled trial }\end{array}$ & $\begin{array}{c}\text { To determine if the Mediterranean } \\
\text { diet would reduce TMAO } \\
\text { concentrations }\end{array}$ & $\begin{array}{l}\text { Results suggest that broad } \\
\text { dietary pattern interventions } \\
\text { over six months may not be } \\
\text { sufficient for reducing TMAO } \\
\text { levels. }\end{array}$ \\
\hline $\begin{array}{l}\text { Liu et al } \\
\quad(47)\end{array}$ & 2018 & $\begin{array}{l}671 \text { PLC cases } \\
\text { and } 671 \text { controls }\end{array}$ & $\begin{array}{l}\text { Case-control } \\
\text { study }\end{array}$ & $\begin{array}{l}\text { To measure TMAO and choline } \\
\text { levels of serum and their } \\
\text { association with the PLC risk }\end{array}$ & $\begin{array}{l}\text { Higher serum levels of TMAO } \\
\text { were associated with an } \\
\text { increased PLC risk. }\end{array}$ \\
\hline $\begin{array}{l}\text { Mondul } \\
\text { et al (48) }\end{array}$ & 2015 & $\begin{array}{l}200 \text { cases }(100 \\
\text { aggressive } \\
\text { cases) and } 200 \\
\text { controls }\end{array}$ & Cohort study & $\begin{array}{l}\text { Prospective analysis of prostate } \\
\text { cancer concerning Alpha- } \\
\text { Tocopherol and Beta Carotene }\end{array}$ & $\begin{array}{l}\text { Positive associations between } \\
\text { TMAO and prostate cancer }\end{array}$ \\
\hline $\begin{array}{l}\text { Bag et al } \\
\quad(49)\end{array}$ & 2015 & $\begin{array}{l}18 \text { specimens } \\
\text { were confirmed } \\
\text { as OSCC } \\
\text { and } 12 \text { as the } \\
\text { control group }\end{array}$ & $\begin{array}{l}\text { Cross } \\
\text {-sectional }\end{array}$ & $\begin{array}{l}\text { Metabolomics alterations in oral } \\
\text { cancer }\end{array}$ & $\begin{array}{l}\text { Trimethylamine } \mathrm{N} \text {-oxide is an } \\
\text { important metabolic signature } \\
\text { for oral cancer. }\end{array}$ \\
\hline $\begin{array}{l}\text { Xu et al } \\
(46)\end{array}$ & 2015 & $\begin{array}{l}\text { a comprehensive } \\
\text { database of } \\
\text { human genes }\end{array}$ & $\begin{array}{l}\text { Experimental } \\
\text { framework for } \\
\text { human genes }\end{array}$ & $\begin{array}{l}\text { Presenting an unbiased data- } \\
\text { driven network-based systems } \\
\text { approach to uncovering a } \\
\text { potential genetic relationship } \\
\text { between TMAO and CRC }\end{array}$ & $\begin{array}{c}\text { Results show that TMAO is } \\
\text { genetically associated with } \\
\text { CRC. }\end{array}$ \\
\hline
\end{tabular}




\section{Discussion}

Several studies have addressed an association between high intake of animal source foods, being a potential causative factor for an increase in serum TMAO levels and cancer disease, in particular colorectal cancers (CRC). A genomewide analysis performed by $\mathrm{Xu}$ et al showed that TMAO, produced by dietary intake of red meat, may genetically have a strong relationship with CRC [36, 37]. New findings demonstrate that even diets have an important effect on the composition of microbiomes existing in the gut. Diets can also alter certain types of gut microbiomes to generate TMA from their precursors existing in animal source foods, thereby resulting in higher serum TMAO levels [38]. The colon contains numerous microorganisms, so dietary changes may be responsible for gut dysbiosis and a reason for promoting progress of colorectal carcinogenesis via multiple mechanisms. These mechanisms are comprised of inflammation, activation of carcinogens and tumorigenic pathways, as well as the damaging of host DNA [39]. A study was conducted on germ-free mice. The mice were transfaunated with rice bran-modified microbiota collected from human stool during fecal microbiota transplant. The results showed that TMAO and tartrate, being associated with CRC development, were reduced in murine colon tissues [40].

Nevertheless, these findings may vary under different circumstances. A study was conducted in healthy adults on the consumption of a Mediterranean diet for six months to determine if a high-fiber diet would reduce plasma concentrations of TMAO as an appropriate selection for reducing the risk of colon cancers. Accordingly, Griffin et al suggested that there was no significant correlation between consumption of the Mediterranean diet and plasma TMAO concentrations in healthy adults [41]. Vegetarian diets, by altering composition of gut microbiota, reduced TMAO production [42].

A randomized controlled trial showed that consumption of animal source foods, in particular fish, was associated with a significant increase in circulated TMAO levels in healthy young men [43]. In another study conducted by Kruger et al, it was reported that consumption of animal source foods had a positive correlation with an increase in circulatory TMAO levels [44]. Several studies indicate that consumption of certain animal source foods, in particular fish, is the reason for having a significant increase in TMAO production; however, it could not be concluded that such foods are certainly responsible for increasing the risk of cancer. Besides, fish consumption is associated with the intake of certain health-promoting compounds, with protective effects on cancer.

A meta-analysis with 42 studies demonstrated that fish intake could even be protective against certain types of cancers, in particular gastrointestinal cancers (GIC), by reducing their risk [45]. On the other hand, TMAO may be an important intermediate marker linking dietary meat, fat, and gut microbiota metabolism to the risk of CRC [46]. Serum TMAO concentrations can contribute to the incidence of different types of cancers, such as primary liver cancer (PLC), as shown in a study conducted by Liu et al. In their study, they found an association between higher serum TMAO concentrations and PLC risks [47].

In a cohort study in Finland, a positive correlation was observed between increased levels of plasma TMAO with the risk of aggressive prostate cancer [48]. This result was supported by other studies indicating that patients with oral squamous cell carcinoma have a higher Serum level of TMAO than healthy controls [49].

Inconsistent with other studies, a study found no relationship between TMAO levels and CRC risks [15]. Differences in results could be explained by the inclusion of different covariates in multivariate logistic regression analyses.

Limitations of previous studies were disregarding kidney function as well as consumption of probiotic and gut-blood barrier permeability as the confounder.

In previous articles, we discussed about glucose and glutamine restrictions along with the increase in non-fermentable ketones for cancer treatment [50-53].

It is suggested that TMAO Should be considered in dietary interventions for cancer prevention and treatment purposes. It is worth noting that modulation of the composition of intestinal microbiota by dietary interventions can result in a reduction in production levels of TMA and TMAO.

In general, a considerable body of evidence is needed to suggest whether TMAO production is correlated with the increased risk of certain cancers.

\section{Conclusion}

Elevated levels of TMAO production could potentially be associated with developments of different types of cancers, particularly CRC. TMAO can be produced by intestinal bacteria from TMA precursors in ingested foods. Further studies are needed on the relationship between intestinal microbiota and cancer. 


\section{Acknowledgement}

We would like to extend special thanks to Dr. Mohammad Reza Ghotbi for reviewing this manuscript.

Conflict of interest: None declared.

\section{References}

1. Erratum: Global cancer statistics 2018: GLOBOCAN estimates of incidence and mortality worldwide for 36 cancers in 185 countries. CA Cancer J Clin 2020; 70(4):313.

2. Institute of Medicine (US) Committee on Cancer Control in Low- and Middle-Income Countries. Cancer Control Opportunities in Low- and Middle-Income Countries. Sloan FA, Gelband $\mathrm{H}$, editors. Washington (DC): National Academies Press (US); 2007. Chapter 2, Cancer causes and risk factors and the elements of cancer control.

3. Gold EB, Gordis L, Diener MD, Seltser R, Boitnott JK, Bynum TE, et al. Diet and other risk factors for cancer of the pancreas. Cancer 1985; 55(2):460-7.

4. Wu S, Powers S, Zhu W, Hannun YA. Substantial contribution of extrinsic risk factors to cancer development. Nature 2016; 529(7584):43-7.

5. Chhibber-Goel J, Singhal V, Parakh N, Bhargava B, Sharma A. The Metabolite Trimethylamine-N-Oxide is an Emergent Biomarker of Human Health. Curr Med Chem 2017; 24(36):3942-53.

6. Raymond JL, Morrow K. Krause and Mahan's Food \& the Nutrition Care Process. 15th ed. Philadelphia, United States: Saunders; 2020.

7. Demarquoy J, Georges B, Rigault C, Royer MC, Clairet A, Soty $M$, et al. Radioisotopic determination of L-carnitine content in foods commonly eaten in Western countries. Food Chem 2004; 86(1):137-42.

8. Zeisel SH, da Costa KA. Choline: an essential nutrient for public health. Nutr Rev 2009; 67(11):615-23.

9. Wang Z, Klipfell E, Bennett BJ, Koeth R, Levison BS, Dugar B, et al. Gut flora metabolism of phosphatidylcholine promotes cardiovascular disease. Nature 2011; 472(7341):57-63.

10. Tang WH, Wang Z, Levison BS, Koeth RA, Britt $\mathrm{EB}, \mathrm{Fu} \mathrm{X}$, et al. Intestinal microbial metabolism of phosphatidylcholine and cardiovascular risk. N Engl J Med 2013; 368(17):1575-84.

11. Koeth RA, Wang Z, Levison BS, Buffa JA, Org E, Sheehy BT, et al. Intestinal microbiota metabolism of I-carnitine, a nutrient in red meat, promotes atherosclerosis. Nat Med 2013; 19(5):576-85.

12. Chamcheu JC, Navsaria H, Pihl-Lundin I, Liovic $M$, Vahlquist $A$, Törmä $H$. Chemical chaperones protect epidermolysis bullosa simplex keratinocytes from heat stress-induced keratin aggregation: involvement of heat shock proteins and MAP kinases. J Invest Dermatol 2011; 131(8):1684-91.

13. Trøseid M, Ueland T, Hov JR, Svardal A, Gregersen I, Dahl CP, et al. Microbiota-dependent metabolite trimethylamine- $\mathrm{N}$-oxide is associated with disease severity and survival of patients with chronic heart failure. J Intern Med 2015; 277(6):717-26.

14. Tang WH, Wang Z, Kennedy DJ, Wu Y, Buffa JA, Agatisa-Boyle B, et al. Gut microbiotadependent trimethylamine $\mathrm{N}$-oxide (TMAO) pathway contributes to both development of renal insufficiency and mortality risk in chronic kidney disease. Circ Res 2015; 116(3):448-55.

15. Oellgaard J, Winther SA, Hansen TS, Rossing $\mathrm{P}$, von Scholten BJ. Trimethylamine $\mathrm{N}$-oxide (TMAO) as a New Potential Therapeutic Target for Insulin Resistance and Cancer. Curr Pharm Des 2017; 23(25):3699-712.

16. Zitvogel L, Galluzzi L, Viaud S, Vétizou M, Daillère $R$, Merad $M$, et al. Cancer and the gut microbiota: an unexpected link. Sci Transl Med 2015; 7(271):271ps1.

17. Ufnal M, Zadlo A, Ostaszewski R. TMAO: A small molecule of great expectations. Nutrition 2015; 31(11-12):1317-23.

18. Zeisel SH, da Costa KA. Choline: an essential nutrient for public health. Nutr Rev 2009; 67(11):615-23.

19. Bennett BJ, de Aguiar Vallim TQ, Wang Z, Shih DM, Meng $Y$, Gregory J, et al. Trimethylamine$\mathrm{N}$-Oxide, a metabolite associated with atherosclerosis, exhibits complex genetic and dietary regulation. Cell Metab 2013; 17(1):4960.

20. Coutinho-Wolino KS, de F Cardozo LFM, de Oliveira Leal V, Mafra D, Stockler-Pinto MB. Can diet modulate trimethylamine $\mathrm{N}$-oxide (TMAO) production? What do we know so far? Eur J Nutr 2021; doi:10.1007/s00394-02102491-6

21. Oellgaard J, Winther SA, Hansen TS, Rossing $\mathrm{P}$, von Scholten BJ. Trimethylamine $\mathrm{N}$-oxide (TMAO) as a New Potential Therapeutic Target for Insulin Resistance and Cancer. Curr Pharm Des 2017; 23(25):3699-712.

22. Bartsch H, Montesano R. Relevance of nitrosamines to human cancer. Carcinogenesis 1984; 5(11):1381-93.

23. Guertin KA, Li XS, Graubard BI, Albanes D, Weinstein SJ, Goedert JJ, et al. Serum Trimethylamine $\mathrm{N}$-oxide, Carnitine, Choline, and Betaine in Relation to Colorectal Cancer Risk in the Alpha Tocopherol, Beta Carotene Cancer Prevention Study. Cancer Epidemiol Biomarkers Prev 2017; 26(6):945-52.

24. Liu X, Liu H, Yuan C, Zhang Y, Wang W, Hu S, et al. Preoperative serum TMAO level is a new prognostic marker for colorectal cancer. Biomark Med 2017; 11(5):443-7. 
25. Bae S, Ulrich CM, Neuhouser ML, Malysheva $\mathrm{O}$, Bailey LB, Xiao L, et al. Plasma choline metabolites and colorectal cancer risk in the Women's Health Initiative Observational Study. Cancer Res 2014; 74(24):7442-52.

26. Georgescauld F, Mocan I, Lacombe ML, Lascu I. Rescue of the neuroblastoma mutant of the human nucleoside diphosphate kinase A/nm23$\mathrm{H} 1$ by the natural osmolyte trimethylamine- $\mathrm{N}$ oxide. FEBS Lett 2009; 583(4):820-4.

27. Kirby TW, Derose EF, Beard WA, Shock DD, Wilson SH, London RE. Substrate rescue of DNA polymerase $\beta$ containing a catastrophic L22P mutation. Biochemistry 2014; 53(14):2413-22.

28. Bhat MY, Singh LR, Dar TA. Trimethylamine Noxide abolishes the chaperone activity of $\alpha$ casein: an intrinsically disordered protein. Sci Rep 2017; 7(1):6572.

29. Bonuccelli G, Castello-Cros R, Capozza F, Martinez-Outschoorn UE, Lin Z, Tsirigos A, et al. The milk protein $\alpha$-casein functions as a tumor suppressor via activation of STAT1 signaling, effectively preventing breast cancer tumor growth and metastasis. Cell Cycle 2012; 11(21):3972-82.

30. Seldin MM, Meng Y, Qi H, Zhu W, Wang Z, Hazen SL, et al. Trimethylamine N-Oxide Promotes Vascular Inflammation Through Signaling of Mitogen-Activated Protein Kinase and Nuclear Factor-kB. J Am Heart Assoc 2016; 5(2):e002767.

31. Rohrmann S, Linseisen J, Allenspach M, von Eckardstein A, Müller D. Plasma Concentrations of Trimethylamine-N-oxide Are Directly Associated with Dairy Food Consumption and Low-Grade Inflammation in a German Adult Population. J Nutr 2016; 146(2):283-9.

32. Xuan C, Shamonki JM, Chung A, DiNome ML, Chung M, Sieling PA, et al. Microbial dysbiosis is associated with human breast cancer. PloS One 2014; 9(1):e83744.

33. Brawner KM, Morrow CD, Smith PD. Gastric microbiome and gastric cancer. Cancer J 2014; 20(3):211-6.

34. Li T, Chen Y, Gua C, Li X. Elevated Circulating Trimethylamine N-Oxide Levels Contribute to Endothelial Dysfunction in Aged Rats through Vascular Inflammation and Oxidative Stress. Front Physiol 2017; 8:350.

35. Federico A, Morgillo F, Tuccillo C, Ciardiello F, Loguercio C. Chronic inflammation and oxidative stress in human carcinogenesis. Int $\mathrm{J}$ Cancer 2007; 121(11):2381-6.

36. Xu R, Wang Q, Li L. A genome-wide systems analysis reveals strong link between colorectal cancer and trimethylamine $\mathrm{N}$-oxide (TMAO), a gut microbial metabolite of dietary meat and fat. BMC Genomics 2015; 16 Suppl 7(Suppl 7):S4.

37. Norat $T$, Bingham $S$, Ferrari $P$, Slimani N, Jenab $M$, Mazuir $M$, et al. Meat, fish, and colorectal cancer risk: the European Prospective
Investigation into cancer and nutrition. J Natl Cancer Inst 2005; 97(12):906-16.

38. Chan CWH, Law BMH, Waye MMY, Chan JYW, So WKW, Chow KM. Trimethylamine-N-oxide as One Hypothetical Link for the Relationship between Intestinal Microbiota and Cancer Where We Are and Where Shall We Go? J Cancer 2019; 10(23):5874-82.

39. Kaźmierczak-Siedlecka K, Daca A, Fic M, van de Wetering T, Folwarski M, Makarewicz W. Therapeutic methods of gut microbiota modification in colorectal cancer management fecal microbiota transplantation, prebiotics, probiotics, and synbiotics. Gut Microbes 2020; 11(6):1518-30.

40. Parker KD, Maurya AK, Ibrahim H, Rao S, Hove PR, Kumar D, et al. Dietary Rice Bran-Modified Human Gut Microbial Consortia Confers Protection against Colon Carcinogenesis Following Fecal Transfaunation. Biomedicines 2021; 9(2):144.

41. Griffin LE, Djuric Z, Angiletta CJ, Mitchell CM, Baugh ME, Davy KP, et al. A Mediterranean diet does not alter plasma trimethylamine $\mathrm{N}$ oxide concentrations in healthy adults at risk for colon cancer. Food Funct 2019; 10(4):2138-47.

42. Koeth RA, Wang Z, Levison BS, Buffa JA, Org $E$, Sheehy $B T$, et al. Intestinal microbiota metabolism of L-carnitine, a nutrient in red meat, promotes atherosclerosis. Nat Med 2013; 19(5):576-85.

43. Cho CE, Taesuwan S, Malysheva OV, Bender E, Tulchinsky NF, Yan J, et al. Trimethylamine$\mathrm{N}$-oxide (TMAO) response to animal source foods varies among healthy young men and is influenced by their gut microbiota composition: A randomized controlled trial. Mol Nutr Food Res 2017; 61(1). doi: 10.1002/mnfr.201600324

44. Krüger R, Merz B, Rist MJ, Ferrario PG, Bub A, Kulling SE, et al. Associations of current diet with plasma and urine TMAO in the KarMeN study: direct and indirect contributions. Mol Nutr Food Res 2017; 61(11). doi: 10.1002/mnfr.201700363

45. Yu XF, Zou J, Dong J. Fish consumption and risk of gastrointestinal cancers: a meta-analysis of cohort studies. World J Gastroenterol 2014; 20(41):15398-412.

46. Xu R, Wang Q, Li L. A genome-wide systems analysis reveals strong link between colorectal cancer and trimethylamine $\mathrm{N}$-oxide (TMAO), a gut microbial metabolite of dietary meat and fat. BMC Genomics 2015; 16 Suppl 7(Suppl 7):S4.

47. Liu ZY, Tan XY, Li QJ, Liao GC, Fang AP, Zhang DM, et al. Trimethylamine $\mathrm{N}$-oxide, a gut microbiota-dependent metabolite of choline, is positively associated with the risk of primary liver cancer: a case-control study. Nutr Metab (Lond) 2018; 15:81.

48. Mondul AM, Moore SC, Weinstein SJ, Karoly ED, Sampson JN, Albanes D. Metabolomic analysis of prostate cancer risk in a prospective cohort: The alpha-tocopherol, beta-carotene 
cancer prevention (ATBC) study. Int J Cancer 2015; 137(9):2124-32.

49. Bag S, Banerjee DR, Basak A, Das AK, Pal M, Banerjee R, et al. NMR ((1) H and (13)C) based signatures of abnormal choline metabolism in oral squamous cell carcinoma with no prominent Warburg effect. Biochem Biophys Res Commun 2015; 459(4):574-8.

50. Khodabakhshi A, Akbari ME, Mirzaei HR, Mehrad-Majd H, Kalamian M, Davoodi SH. Feasibility, Safety, and Beneficial Effects of MCT-Based Ketogenic Diet for Breast Cancer Treatment: A Randomized Controlled Trial Study. Nutr Cancer 2020; 72(4):627-34.

51. Khodabakhshi A, Seyfried TN, Kalamian M,
Beheshti M, Davoodi SH. Does a ketogenic diet have beneficial effects on quality of life, physical activity or biomarkers in patients with breast cancer: a randomized controlled clinical trial. Nutr J 2020; 19(1):87.

52. Khodabakhshi A, Akbari ME, Mirzaei HR, Seyfried TN, Kalamian M, Davoodi SH. Effects of Ketogenic metabolic therapy on patients with breast cancer: A randomized controlled clinical trial. Clin Nutr 2021; 40(3):751-8.

53. Khodabakhshi A, Mahmoudi M, Mehrad Majd H, Davoodi SH. Possible Nutrition-Related Mechanisms of Metabolic Management in Cancer Treatment. Int J Cancer Manag 2021; 14(1):e107678. 